УДК 341.9

\title{
The Main Characteristics of the Hague Principles
}

\author{
Marianna A. Kalashyan* \\ Russian-Armenian (Slavonic) University \\ 123 Hovsep Emin Str., Yerevan, 0051, Armenia
}

Received 04.05.2016, received in revised form 20.07.2016, accepted 03.08.2016

\begin{abstract}
The article considers legal issues of the Hague Principles on the choice of law in international commercial contracts. The experience of approving the Hague Principles is unique in the long-term practice of the Hague Conference on Private International Law in connection with the fact that for the first time it approved an international instrument in the form of a set of advisory rules. Regulation of international commercial relations by the non-state instruments is frequently implemented nowadays. The article determines the criteria for the non-governmental instruments as the basis for their recognition as a control for cross-border relations.
\end{abstract}

Keywords: Hague Conference on Private International Law, Hague Principles, choice of law, international commercial relations, non-state instruments.

DOI: 10.17516/1997-1370-2016-9-8-1910-1915.

Research area: law.

One of the major objectives of the rules of private international law is to achieve a high level of coordination and cooperation between national legal systems and, consequently, ensure legal certainty in the regulation of cross-border private relations. To achieve this goal a variety of different-level methods and tools of convergence of law is applied. Their pluralism characterizes the current PIL. As R. David noted, the concept of unification of private law should be perceived in a fairly broad sense. The progress of the process of international law unification can be achieved by various means (René, 1968, 13). The researcher notes that the means and methods of unification should not be opposed, but are designed to complement each other. None of these methods can be absolute and recognized as an instrument of unification par excellence (René, 1968).

Basing on this statement, let us consider the main characteristics of the Hague Principles on the choice of law applicable to international commercial contracts (hereinafter - the Hague Principles), which received official approval on March 19, 2015.

Let us note that since 2006, the Hague Conference on Private International $\mathrm{Law}^{1}$ had been developing the draft Hague Principles. In April 2013, the draft Hague Principles were approved by the Special Commission of the Hague Conference, together with detailed paragraph-

(c) Siberian Federal University. All rights reserved

* Corresponding author E-mail address: marian.kalashyan@gmail.com 
by-paragraph commentaries. These Principles, as stated in the commentaries are guidelines to "best practices" (Hague Conference on Private International Law, 2015, 23).

Experience of the adoption of the Hague Principles is unique in the long-term practice of the Hague Conference on Private International Law in connection with the fact that for the first time this organization approved an international instrument in the form of a set of rules, which are advisory and non-binding.

According to I.S. Zykin, the adoption of a set of rules as a document, which is not legally binding, to a certain extent allows to avoid formal discrepancies between the Hague Principles and binding regulations, including those contained in the Regulations "Rome I", the Inter-American Convention 1994 and Hague Conventions in this field (Zykin, 2016, 75).

It seems that the trend of settling international commercial relations with the nonstate instruments is a common practice nowadays. In this sense, the Hague Principles have supplemented UNIDROIT Principles, Principles of European Contract Law and other widely used principles of cross-border commercial relations, acting as an innovative legal advisory instrument. The development of these Principles in a "soft" form should deepen the process of harmonizing conflict approaches to the choice of law applicable to international contracts in private international law in various countries. First of all, the Principles have been designed to create a universal model of conflict rules to the choice of law applicable to international contracts, including through interpretation, additions and development of current rules, and are assumed as a legislative model for national, regional, supranational and international instruments (Choice of Law in International Contracts: Development Process of the Draft Instrument and Future Planning, 2012).
However, the Hague Conference does not exclude the possibility of developing a formal binding document in the future. However, the chosen form is more appropriate to the requirements of the present time.

The Principles as a whole are devoted to the development and expansion of the party autonomy. Despite the fact that the party autonomy is one of the most common and recognized principles of PIL of different countries, however, the development of approaches to such controversial issues as the limits of parties' choice, the application of nonstate rules of law to cross-border legal relations, the problem of changing rule of law or the practice of its application at the time of the dispute remains quite urgent.

Therefore, there are many issues regarding the choice of the applicable law, despite the apparent uniformity of the approach, which prove the timeliness and relevance of the development of the Hague Principles.

Since the elaboration of the draft text of the Hague Principles and after their adoption in 2015 the attention of researchers was focused on the analysis of the innovations that they contained. One of the main features of the Hague Principles is the possibility of using them by national courts and arbitration tribunals as provided for in the preamble. It is important to note that the commentary to the Hague Principles reveals the purpose of such application by the specified recipients. In particular, national courts and arbitration tribunals apply the Principles in order:

- to interpret and understand the meaning of the current rules of private international law;

- to supplementand develop the regulations of private international law, which do not provide appropriate regulation in specific situations;

- to develop rules of private international law and new rules (by legislative bodies or courts), 
which had not existed before, or to change the current rules fundamentally (Hague Conference on Private International Law, 2015).

In our opinion, the Hague Principles and detailed commentaries to them, as well as other similar instruments, should be studied not only by researchers, but also by practitioners.

According to S. Symeonides, the role and importance of the Hague Principles from a scientific point of view are obvious. As for the application and acceptance of these Principles by the parties of cross-border private-law relationships, it all depends on the respective legal practices (Symeonides, Symeon, C., 2013).

We consider it necessary to note that in September 2016 Switzerland will host a conference dedicated to the issues of realization of the Hague Principles. The conference will be attended by researchers, experts and practitioners. One of the key issues to be discussed at the conference will be the statement of the Hague Principles, which, probably, was the subject of the greatest scientific interest of specialists: the issue of choosing nonstate rules or rules of "soft" law. According to Art. 2 (1) of the Hague Principles "a contract is governed by the law chosen by the parties" (Hague Conference on Private International Law, 2015). Further, Art. 3 of the Principles specifies that the law chosen by the parties also includes the rules of law accepted on an international, supranational or regional level as a neutral set of rules, unless the national law provides otherwise. The possibility of such a reference to nonnational rules extends the party autonomy, allows to ensure the economic interests of the parties of cross-border relations, acting as an innovative approach for the majority of legislations.

The value of the Hague Principles, as well as any other set of non-binding rules, is differently assessed in the current scientific literature: from complete denial to acceptance. Criticism is mainly focused on the freedom to choose non-national sources as regulators of the contractual relationship of the parties provided in the instrument. For example, M.V. Mazhorina considering the legal nature of the rules contained in the non-state sources of origin, i.e. transnational rules, raises the question, whether "it is really rightful to interpret the principle of 'the party autonomy' so broadly, to come to the conclusion that the parties of cross-border transaction may choose 'something' that is not the law in the formal legal sense of the word as applicable to the contract" (Mazhorina 2015, 47). Of course, the issue of understanding the nature of transnational legal rules is today one of the most, perhaps, topical and controversial in international private law theory. However, when dealing with this very complicated issue, it is important to bear in mind modern trends in international legal practice development that cannot be ignored.

In recent editions, the role and importance of the Hague Principles is assessed as "an important indicator of trends in the development of the definition of the law applicable to contracts, aimed at expanding the sources of possible choice of the applicable law, allowing the choice of "rules of law", and, accordingly, the UNIDROIT Principles, not only in the consideration of disputes by the international commercial arbitration, but by state courts" (Bardin, 2016, 20).

In our view, the expansion of the party autonomy in cross-border contracts on the choice of non-state rules should not cause any concern. And here we agree with the view of A. Asoskov, which rightfully says, "the parties of crossborder agreement concluded in terms of business activities, should be given the choice of nonnational sources as the applicable law, provided that such non-national sources are a relatively complete system of legal regulations that can independently fill the gaps of legal regulation, and comply with the basic principles of private law, as well as are protected from possible abuses 
by establishing mandatory rules which cannot be excluded by the agreement of the parties" (Asoskov 2012, 13). This position is based on the recognition of the concept of the interests and party autonomy in cross-border relations, as well as on the principle of protection of national law and order.

We consider it necessary to note that the use of the term 'non-legal regulation' (Mazhorina $2015,49)$ for the characteristics of transnational rules instead of 'non-national' or 'non-state' is, in our view, unacceptable. The fact that the rules being considered do not have the state origin does not mean that they are non-legal ${ }^{2}$.

Returning to the text of the Hague Principles, let us note that they contain an approach already established in the practice, in particular, of arbitration bodies: non-state or non-national rules should be developed in the form of a complete set of rules; be accepted as neutral and balanced. In our view, this approach is the key and innovative one among a small number of the provisions of the Hague Principles. We share the position of I.S. Zykin that the Hague Principles try to set the criteria for non-national sets of rules and principles (Zykin, 2016, 83). Moreover, we believe that the Hague Principles made the first attempt to outline these criteria. Of course, researchers immediately began to criticize the criteria for their uncertainty and assessment nature. Criticism, of course, is appropriate, and it is difficult not to agree with the arguments of the experts, but we believe that without falling into euphoria regarding the role of non-national rules, it would be fair to note the beginning of a new milestone in the development of codes of transnational rules. The doctrine of private international law should play the key role in the development of the criteria in terms of further specification and certainty.

The above arguments allow us to note that the instruments of the non-national origin as a basis for their recognition as the control of crossborder relations should:

- reflect and base on the legal doctrine;

- be consistent;

- generalize common approaches;

- be neutral and balanced sets;

- be developed by expert organizations and recognized centres established for the purpose of convergence of rules, or if they have this purpose as one of the main ones.

Development of the given criteria requires further work in both research and practical areas.

\footnotetext{
1 On September 16, 2014, the Constitutional Court of the Republic of Armenia recognized the obligations provided for by the Statute of the Hague Conference on Private International Law (entered into force on July 15, 1955) as corresponding to the Constitution of the Republic of Armenia. In April 2015, Armenia became the 79th member of the Hague Conference. Thus, we have joined the long-term work on the progressive unification of the rules of private international law (Art. 1 of the Statute of the Hague Conference on Private International Law), as an official member of the international organization. However, it should be noted that the possibility of acceding to the conventions of the Hague Conference is provided regardless of the membership, which allowed Armenia to join international agreements developed within the organization before 2015 .

2 This issue should be the subject of an independent research work.
}

\section{References}

Asoskov, A.V. (2012). Normoobrazuiushchie factory, vliiaiushchie na soderzhanie kollizionnogo regulirovaniia dogovornykh obiazatel'stv [Rule-setting factors, which influence the content of the conflict regulation of the contract obligations]. Author's abstract of the thesis (Doctor of Legal Sciences), $53 \mathrm{p}$.

Bardina, M.P. (2016). Osnovanie primeneniia Printsipov mezhdunarodnykh kommerchskikh dogovorov UNIDRUA pri razreshenii mezhdunarodnykh kommercheskikh sporov po sushchestvu spora [Basis for applying the UNIDROIT Principles of international commercial contracts in settlement of 
international commercial disputes on the merits of the dispute], In Sbornik statei "Aktual'nye pravovye aspekty sovremennoi praktiki mezhdunarodnogo torgovogo oborota" [Actual legal aspects of modern practice of international trade turnover], Moscow, 6-21.

Choice of Law in International Contracts: Development Process of the Draft Instrument and Future Planning (2012). Preliminary 4 of January 2012 for the attention of the Council of April 2012 on General Affairs and Policy of the Conference. Available at: http://www.hcch.net/index_en.php?act=text. display\&tid $=49$

Mazhorina, M.V. (2015). Novye Gaagskie printsipy o vybore prava, primenimogo k mezhdunarodnym kommercheskim kontraktam: ob avtonomii voli storon v svete global'nykh izmenenii v prave mezhdunarodnoi torgovli [New Hague Principles on the choice of law applicable to international commercial contract: on the party autonomy in terms of global change in the international trade law], Zhurnal pravovykh i ekonomicheskikkh issledovanii [Journal of Legal and Economic Studies], 45-50.

Principles on Choice of Law in International Commercial Contracts (2015), Hague Conference on Private International Law, Hague, Netherlands.

Symeonides, Symeon, C. (2013). The Hague Principles on Choice of Law for International Contracts: Some Preliminary Comments, Revue critique de droit international privé, 13. Available at: http://ssrn.com/abstract=2256661

René David. (1968). The Methods of Unification, American Journal of Comparative Law, 6 (182), 13. Available at: http://www.cisg.law.pace.edu/cisg/biblio/david.html

Zykin, I.S. (2016). Gaagskie printsipy o vybore primenimogo prava k mezhdunarodnym kommercheskim dogovoram [The Hague Principles on the choice of law applicable to international commercial contracts], In Sbornik statei "Aktual'nye pravovye aspekty sovremennoi praktiki mezhdunarodnogo torgovogo oborota" [Actual legal aspects of modern practice of international trade turnover], Moscow, 73-94.

\title{
Основные характеристики
}

\section{Гаагских принципов}

\author{
Марианна А. Калашян \\ Российско-Армянский (Славянский) университет \\ Армения, 0051, Ереван, ул. Овсепа Эмина, 123
}

\footnotetext{
В статье рассматриваются вопросы правовой природы Гаагских принципов о выборе права, применимого к международным коммерческим договорам. Опыт принятия Гаагских принципов является уникальным в многолетней практике Гаагской конференции по международному частному праву в связи с тем, что впервые в рамках данной организачии принят международный документ в форме свода правил, имеющего рекомендательный характер. Представляется, что тенденция урегулирования международных коммерческих отношений инструментами негосударственного характера сегодня является распространенной практикой. Выделены критерии, которым, по мнению автора, должны соответствовать инструменты негосударственного происхождения в качестве основания для признания их в качестве регулятора трансграничных отночений.
} 
Ключевые слова: Гаагская конференция по международному частному праву, Гаагские приниипы, выбор права, международные коммерческие отношения, инструменты ненационального происхождения.

Научная специальность: 12.00.00 - юридические науки. 